\title{
Lodz City Tour: The Changing Nature of the Urban Restructuring of a Post-Socialist Industrial City
}

\section{EN}

This is an Accepted Manuscript of an article published by Taylor \& Francis in disP - The Planning Review on 17 Jul 2020, available online:

https://doi.org/10.1080/02513625.2020.1794119

\section{How to cite:}

Zasina, J., Sokołowicz, M.E., \& Nogalski, S. (2020). Lodz City Tour: The Changing Nature of the Urban Restructuring of a Post-Socialist Industrial City. disP - The Planning Review 56(2), 8-19, https://doi.org/10.1080/02513625.2020.1794119

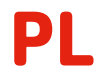

To zaakceptowany manuskrypt artykułu wydanego przez Taylor \& Francis w czasopiśmie disP - The Planning Review w dniu 17.07.2020 r. i dostępnego online: https://doi.org/10.1080/02513625.2020.1794119

\section{Jak cytować:}

Zasina, J., Sokołowicz, M.E., \& Nogalski, S. (2020). Lodz City Tour: The Changing Nature of the Urban Restructuring of a Post-Socialist Industrial City. disP - The Planning Review 56(2), 8-19, https://doi.org/10.1080/02513625.2020.1794119 


\title{
Lodz City Tour:
}

\section{The changing nature of}

\section{the urban restructuring of a post-socialist industrial city}

\author{
Jakub ZASINA \\ Affiliation: University of Lodz, Faculty of Economics and Sociology, Institute of Spatial Economy, Lodz, Poland. \\ ORCID: https://orcid.org/0000-0001-7519-6982. \\ Biographical note: Jakub Zasina is an assistant professor specialising in urban studies and economic geography at the University of Lodz. \\ His main interests focus on studentification, and social media image of urban environments. Before entering an academic career, he was \\ a project manager in city-focused NGOs.
}

\section{Mariusz E. SOKOŁOWICZ}

Affiliation: University of Lodz, Faculty of Economics and Sociology, Institute of Spatial Economy, Lodz, Poland. ORCID: https://orcid.org/0000-0002-0716-4345.

Biographical note: Mariusz E. Sokotowicz, born in Lodz, Poland, is an academic and an urban activist. He is a professor at the University of Lodz, specialising in urban economics, institutional economics and place marketing. For several years he worked as a real estate manager and advisor, as well as a local government official responsible for the town centre revitalisation project. He is a participant of numerous projects in Poland and other European countries.

\section{Szymon NOGALSKI}

Affiliation: LDA Design, Cambridge, United Kingdom.

Biographical note: Szymon Nogalski, MAUD, is an urban designer with strong interest in placemaking and broad experience of strategic masterplanning and design advice to local authorities and private clients. Originally from Lodz where he worked at the City Hall, currently resides in Cambridge, UK, where works as a Principal Consultant at LDA Design. Guest critic/tutor at LSE Cities and the University of Lodz.

Corresponding author:

Jakub ZASINA, University of Lodz, Faculty of Economics and Sociology, Institute of Spatial Economy, Department of Regional Economics and Environment, ulica Polskiej Organizacji Wojskowej 3/5, 90-255 Łódź, Poland, jakub.zasina@uni.lodz.pl.

\section{Abstract}

The paper describes the restructuring of Poland's third-largest city, Lodz (Łódź). Once a thriving metropolitan hub of textile and clothing manufacturing, Lodz was confronted with the closure of its numerous factories in the early 1990s with Poland's transition from a planned to a global market economy. The city suffered an abrupt and dramatic decline followed by a redefinition of its economic, spatial and social structures. The paper focuses on the major economic and spatial phenomena taking place in the city in the three decades after the economic collapse. Using an evolutionary approach, it identifies and discusses the gradual shift of Lodz's restructuring. We claim that the restructuring initially involved mostly organic and spontaneous initiatives of dynamic local and non-local actors, with minor and circumstantial involvement from the local authorities. However, over time, the restructuring of Lodz has become influenced 
and driven by nationally and EU-set objectives and targeted urban policies, with urban and infrastructural projects as driving vehicles. 


\section{Introduction}

Unlike many other major Polish cities, Lodz developed as a result of rapid 19th-century industrialisation. Once a thriving metropolis of textile and clothing production, Lodz was confronted with the industry's decline when Poland launched its transition to a global market economy after the fall of communism in 1989. Consequently, Lodz experienced one of the most dramatic shake-ups of the time, with countless social, economic and spatial repercussions. However, speed is just one aspect of Lodz's recent transition. It could also act as a magnifying glass of the challenges affecting Polish cities and the resultant shift in urban policymaking.

After the fall of the centrally planned economy, Lodz resorted to spontaneous, un-coordinated restructuring, intrinsically linked to its textile legacy, as the national policy-making bodies did not recognise a need to have an overarching strategic framework for urban policy. Initially, the gradual shift towards targeted programmes responding to urban challenges manifested itself modestly with the arrival of special economic zone and attempts to attract large-scale manufacturing. Finally, the emergence of locality-sensitive EU and national policymaking tools in the 2000s brought infrastructure-led regeneration. Large projects and the city's growing governance maturity helped define the direction of the city's development.

[Figure 1. near here]

This City Tour begins with an introduction to the historical traits of Lodz's development, highlighting its industrial roots and their impact on today's city. The paper then takes a broad look at the major economic and spatial phenomena that have taken place in the city during the three decades of its ongoing restructuring. Finally, in the concluding remarks, it comments on the nature and stages of Lodz's transition.

\section{The birth, life and death of the industrial metropolis}

Inhabited by 767 residents at the beginning of the 1820s (Badziak, 2009), peripheral Lodz was placed on a new development path by the industrialisation policy of the Kingdom of Poland (a semi-autonomous entity of the Russian Empire) when in 1821, Lodz was granted the status of 'an industrial town', with beneficial settlement rights for those willing to become involved in textile production. Settlers flocked, primarily from Bohemia, Brandenburg, Saxony, Silesia and Wielkopolska, encouraged by free allocated plots of land, a relocation reimbursement, and tax and military conscription exemptions (Jewtuchowicz \& Suliborski, 2009a). These incentives were supplemented by the provision of ready-to-inhabit houses and basic community amenities (Stefański, 2001). The strategic approach, together with external factors (i.a., the demand for textiles in the Russian Empire and favourable trading conditions), kickstarted the rapid growth of the town's population to 20,000 in 1842 (Dzieciuchowicz, 2009a).

At the turn of the 20th century, Lodz had already transformed into an industrial metropolis in a similarly rapid way as its Northern American counterparts, and by 1914, the population had exploded to 500,000. The mass migration of Poles from the countryside and Jews from Russia, together with the community of early German settlers, turned Lodz into a cultural melting pot (Kowalski et al., 2018). Direct access to the markets of the Russian Empire, and their links to the Far East, technological improvements, the emergence of the local banking sector and the influx of workers fuelled the growth of Lodz's economy and placed the city in the leading 
position of textile production (predominantly cotton) in Europe (Jewtuchowicz \& Suliborski, 2009a).

[Figure 2. near here]

[Figure 3. near here]

In spatial terms, Lodz's initial utilitarian grid layout (Figs. $3 \& 4$ ), conceived for the early industrial town, did not meet the needs of the booming population and industrial production, but the city did not undertake any planning or parcellation initiatives between the 1870 s and the 1910s. The city lacked public infrastructure, such as a comprehensive water supply and sewage systems, a sufficient number of schools and hospitals, let alone cultural institutions, with some factory owners attempting to bridge the infrastructural gap through isolated and disjointed initiatives. Prosperous family enterprises became industry giants, and they produced a new typology of self-sufficient urban districts comprising production facilities, owners' residences, housing estates for workers, and the accompanying technical and social infrastructure (Stefański, 2001).

In the years following the re-establishment of Poland's independence (1918), the population of the city continued to grow steadily, reaching 672,000 in 1939 . This was despite the economic turmoil of the Great Depression in the 1920s and 30s, and the loss of lucrative markets in the East as a result of the political tensions between Poland and the Soviet Union (Jewtuchowicz \& Suliborski, 2009b).

The post-war geopolitical order of 1945 placed Lodz in the geographical centre of the newly established People's Republic of Poland. Production - including the textile industry - was nationalised, and Lodz's factories continued operating under state ownership, reoriented again towards the East to serve the Soviet economic sphere. However, the industry did not see any major improvements until the 1970s, when the manufacturing infrastructure was partly modernised. The structure of industrial production in Lodz was only marginally diversified; thus, the post-war Lodz remained a city highly specialised in the textile and clothing industries (Jewtuchowicz \& Suliborski, 2009b).

Nevertheless, after 1945, the predominantly industrial image of Lodz began to change through continued efforts to equip the metropolis with appropriate services and institutions. The central government decided to establish higher education institutions (Zysiak 2016) and construct the city's opera house as well as other cultural venues (Sokołowicz \& Zasina, 2016). The city boundaries were substantially expanded through the incorporation of surrounding villages and the construction of mass housing estates. The 19th-century residential building stock in the centre was neglected, perceived as the politically inappropriate remains of the capitalist past and inadequate for living standards. The population of the city peaked in 1988 (Fig. 11) with 854,261 residents (Dzieciuchowicz, 2009b).

[Figure 4. near here]

The return to a market economy and democracy in Poland in 1989 led to a deep economic restructuring that affected certain parts of the country more than others. At the beginning of the 1990s, Lodz faced rapid deindustrialisation in absolute and relative terms (MarczyńskaWitczak \& Starzyńska, 2002). For instance, the region's textile sales shrank by $40 \%$ between 
1988 and 1991 (Jewtuchowicz \& Suliborski, 2009c). Outdated and labour-intensive technologies, and a shortage of managerial and marketing skills partly explain how textile producers found themselves trapped between more advanced products from the West and cheaper ones from the Far East (Walker, 1993). Furthermore, the state-owned textile companies were not used to operating in highly competitive markets, had low financial liquidity, and were unable to sustain exports to the former socialist states of Eastern Europe (Borkowska \& Bohdziewicz, 1994; Walker, 1993). The economic decline was hard to overcome, as Poland lacked a long-term strategy and short-term programmes for the restructuring and modernisation of the textile and clothing industries that Lodz was based on. The entire institutional system of manufacturing in Lodz, which consisted of factories, R\&D centres, education and trade organisations, ceased (Jewtuchowicz \& Suliborski, 2009c).

Industrial areas were abandoned in just a few years. The neglected city centre, a monument of the city's capitalist past, became the most serious physical challenge that Lodz had faced after the economic and political transformation. As Walker (1993) noticed, Lodz was at that time "[...] in the unenviable position of requiring to combat decades of underinvestment and neglect with a programme of urban refurbishment and revitalisation in an age of bankruptcy." Unemployment, a phenomenon almost unknown in communist Lodz, grew instantly and exceeded 25\% in 1993 (Fig. 12). The scale and consequences were unprecedented when compared to the other regional capitals of Poland. Scarce job opportunities, the proximity of Warsaw, the brain drain of the skilled workforce, and the decreasing quality of life in Lodz, among other factors, accelerated a population decline of $19.5 \%$, from 851,690 in 1989 to 685,285 in 2018.

\section{The organic and spontaneous genesis of urban restructuring}

The local authority had little room to manoeuvre in the events following 1989's transformation. The opportunities to prevent economic collapse were insignificant, while the financial and institutional support from the national government to strategically counteract and mitigate the social, spatial and broader economic consequences of de-industrialisation were inconsistent and scarce. Therefore, the collapse of state-owned companies resulted in the organic, un-aided growth of small and medium-sized enterprises (SMEs) in Lodz. Mid-to-senior level managers and technologists from the bankrupting state-owned companies realised the potential of access to the pool of skilled workers in the city and the availability of necessary machinery and production spaces. Half of the manufacturing firms established in Lodz at that time specialised in textiles or clothing. This rise of entrepreneurialism, together with Lodz's favourable central location, spurred the emergence of large clothing trade centres on the outskirts of the city, attracting wholesale and retail traders from Poland and abroad. The organic development was in line with the dominance of the neo-liberal path of Poland's transformation (Zysiak et al., 2018). This 'self-made' evolution sustained Lodz's textile and clothing specialisation and partly stabilised the tough labour market conditions in the first years of the restructuring; however, it stopped the city's economy from diversifying and transforming into more innovative industries (Jewtuchowicz, 2013). Concurrent with the 'grassroots' entrepreneurship, the city's higher education institutions (HEIs) organically embarked on a path of growth, but it did not 
immediately result in the perception of Lodz as an academic centre. After the collapse of giant industrial companies, some of the local HEIs became Lodz's largest single employers (Buchner-Jeziorska \& Kulpińska, 1996). The capacity of Lodz-based HEIs was estimated at about 20,000 at the beginning of the 1990s, and it was perceived as one of the city's major opportunities for economic restructuring (Walker, 1993). The entrepreneurial approach of the local HEIs quickly multiplied the number of students, harnessing the higher education boom in Poland at the turn of the 1990s and 2000s (Kwiek, 2015). In 2013, 83,471 students (of whom 53,675 were full-time) were registered with six public and 17 private HEIs (Główny Urząd Statystyczny, 2017; Urząd Statystyczny w Lodzi, 2017). The local HEIs became some of the most active developers in the city, investing in the regeneration of historic industrial buildings and complexes, and constructing new facilities clustered around two campuses located in the periphery of the centre (Wolaniuk, 2010).

After the collapse of the state-led textile and clothing production in Lodz, vacated industrial areas were gradually repurposed. Initially, their transformations mainly took the form of makeshift, un-coordinated conversions of buildings into small-scale factories or low-standard offices and spaces for service activities (e.g. craftwork, warehousing, etc.) (Riley, 1997). Some architecturally significant industrial buildings and artefacts were lost through irreversible damage, alteration or destruction, and 'predatory land speculation' (Zysiak et al., 2018). However, from the early 2000s onwards, commercial interest in the post-industrial areas and properties steadily grew, in response to emerging consumerist lifestyles in Poland. The most impressive regenerations of post-industrial areas were undertaken by mostly private, foreign entities in the mid-2000s. They meticulously restored and regenerated some of the largest, most recognisable and challenging industrial areas for new uses. For example, the former Poznański factory became 'Manufaktura', a 25-ha shopping, entertainment and cultural centre (Figs. 5 \& 6). Its significance is particularly remarkable, as it controversially provided a much-anticipated improvement in the quality of 'public' space in Lodz and proved to be a new landmark in the city. The success of Manufaktura created an attractive image of Lodz's post-industrial heritage, setting a precedent for investments in other former factories. Another landmark investment, ' $U$ Scheiblera', a former $207 \mathrm{~m}$ long cotton mill turned into luxury apartments, initiated a 'loftliving fad' in Lodz. Most importantly, these investments changed the public perception of the tangible, industrial legacy of Lodz: it went from being a burden to an asset (Nowakowska \& Walczak, 2016; Rzeńca \& Sokołowicz, 2017).

[Figure 5. near here]

[Figure 6. near here]

Lodz in the 1990s, like other cities in post-socialist European countries, began to re-rediscover its material and non-material legacy, in order to (re)define its identity in the new socioeconomic circumstances. Initially, the efforts were focused on relating back to the entrepreneurial and multinational spirit of the capitalist, 19th-century Lodz, i.e. the 'Promised Land' of business and life opportunities (Fleming, 2012; Young \& Kaczmarek, 2008). The prolonged debate on Lodz's identity started to reach some conclusions in the late 2000s when local NGOs initiated and led the city's bid for the title of European Capital of Culture. However unsuccessful, the process significantly consolidated residents and Lodz's authorities around the 
idea of regenerating the city through culture-related activities. It grounded the 'creative city' concept in the local conscience as a development rationale and resulted in Lodz's subsequent branding strategy as 'The centre of creative industries' ('Centrum przemysłów kreatywnych') (Urząd Miasta Łodzi, 2009; Sokołowicz, 2013).

\section{Public-led urban restructuring on the move}

The scenario of "once a textile town, always a textile town" (Walker, 1993) was identified as a dangerous path for Lodz, as the mature and internationally dispersed textile and clothing industries were already of limited profitability. The first signals of public support for a shift away from textile and clothing production were already visible in the 1990s. The Lodz Special Economic Zone (Łódzka Specjalna Strefa Ekonomiczna, ŁSSE) was established in 1997 to address the problem of the monofunctional economic structure of the city, as a part of the national investment policy. The activities of the ŁSSE allowed the urban economy to diversify, and it created much-awaited jobs, even if initially these were not in advanced technologies. Moreover, in the mid-2000s, the municipality established a programme to attract specific industries, e.g. the manufacturing of white goods and business process outsourcing (BPO), by creating incentives for external investments (Jewtuchowicz \& Suliborski, 2009c; Fleming, 2012).

The location of Lodz in the geographic centre of Poland remained relatively insignificant in the 1990s because of the poor quality of transportation infrastructure. The motorway system did not exist, there were no international flights from the city airport, and the railways did not provide convenient connections to national and European hubs (Walker, 1993). Thus, since the beginnings of Lodz's restructuring, the key notion of local policies was to overcome these shortcomings, mainly by lobbying the Polish government and European agencies for the construction of motorways. These efforts remained limited for many years. The picture changed significantly after Poland's accession to the EU in 2004. The region became a beneficiary of European funds for infrastructure projects, and the long-planned A1 (E75) and A2 (E30) motorways were opened in the early 2010s. The modernisation of the road network attracted the logistics industry to invest in the area between Stryków and Piotrków Trybunalski, capturing Lodz.

In the early 2000s, public investments began to play an increasingly important role in the restructuring of Lodz. Funding streams were strategically targeted and aligned with regeneration objectives. The city's metropolitan aspirations, its proximity to Warsaw, and the release of brownfield sites in the centre led to the redevelopment of the area surrounding the Lodz Fabryczna railway terminus. The project, centring on the complete redevelopment of the station into an underground hub (with a new railway tunnel continuing westwards to link up country's fragmented railway network), was branded the New Centre of Lodz (Nowe Centrum Łodzi, NCŁ) (Hanzl, 2011) and secured significant funding. The initial idea originated from an NGO's proposal to transform a vacated power plant, EC1, into an interactive museum. The vision quickly spurred a wider discussion about a comprehensive transformation of 100 ha of the city centre surrounding EC1 and the railway terminus. The local authorities started to program NCŁ as a district of spectacular architecture, housing new cultural and commercial uses (e.g. the Camerimage Lodz Centre designed by Frank Gehry, Specjalna Strefa Sztuki by 
Moeller Architekten + Ingenieure BDA, and Brama Miasta by Daniel Libeskind). These fanciful aspirations were ultimately revised and tailored to the city's actual needs and financial capabilities, as NCE's area and budget have made it the largest urban redevelopment project in Lodz's history. The new underground Lodz Fabryczna station (Fig. 7) was completed in 2016 (as a terminus; however, the design and construction of a new section of the tunnel, linking it to the other main railway station, is underway). The first parcels in NCŁ have been developed, with a significant share of public regeneration investment focused on cultural, education and leisure uses, such as the abovementioned EC1 power station turned into museums and a congress centre (Fig. 8).

[Figure 7. near here]

[Figure 8. near here]

Despite numerous successful private investments in former industrial buildings and public funds directed at NCŁ, the majority of Lodz's centre remains physically, economically and socially deprived (Fig. 9). Over the decades, there have been some initiatives to increase the city centre's attractiveness and liveability. The 'pedestrianisation' of Lodz's main street, Piotrkowska (Figs. 3 \& 10), in the 1990s, initiated by a local NGO, the Piotrkowska Street Foundation, was the first significant project. In the mid-2000s, the local authority, together with local professionals and academics, conceptualised the PROREVITA programme of the city centre's revitalisation; the implementation of the programme was, however, fragmentary (Markowski \& Turała, 2007). Consequently, those placemaking initiatives in the centre were disconnected in time and space.

[Figures $9 \& 10$. near here]

In this context, Gałuszka (2017) notices that at the turn of the 2000s and 2010s, the situation began to improve, as the regeneration of the city centre gained political importance. The authorities of Lodz began to incorporate into policymaking the ideas, programmes and projects conceptualised by local activists, entrepreneurs and academics. The most significant initiatives include the Town Centre Management-influenced 'Piotrkowska Street Development Strategy' ('Strategia Rozwoju Ulicy Piotrkowskiej') (Boryczka, 2013), the 19th century tenements regeneration programme 'Miasto kamienic' (Jakóbczyk-Gryszkiewicz et al., 2014), shared surface streets (misleadingly nicknamed 'woonerfs' in Lodz), and bicycle infrastructure improvements. Some of these ideas were incubated within the framework of the Lodz participatory budget, itself another initiative conceived by local activists.

Lodz's authorities decided to capitalise on residents' enthusiasm for these activities by integrating similar projects into a large, area-based revitalisation programme. Concurrently, a 
new national framework for urban policies and EU fund allocation were established in $2015^{1}$, and Lodz was positioned to champion the regeneration efforts. The local authority adopted a local revitalisation programme (Urząd Miasta Łodzi, 2018a) that for the first time combined improving the quality of life in the centre and addressing issues in a holistic manner. The programme covers an area of 1783 ha in the centre of the city $(6.08 \%$ of total the administrative area), with a population of 152,292 (ca. 23\% of the city's residents). Within the framework, the local authority wants to accomplish four key goals, i.e.:

1) Social cohesion (by stimulating employment growth, counteracting poverty and sociospatial segregation, improving education chances, as well as promoting social capital);

2) Change perceptions (by improving the cultural landscape and enhancing local identity and improving public spaces);

3) Strengthen local entrepreneurship (by improving conditions for business and promoting entrepreneurial attitudes);

4) Improve the residential offer (through technical upgrades to buildings, infrastructure and public spaces, and enhancing amenities).

Although it is too early to verify the programme's effectiveness, it should be stressed that, for the first time, urban revitalisation has been officially and explicitly included in municipal policy and approached in a systematic, strategic manner. Public funds of 1.4 billion PLN (ca. 0.4 billion EUR) up to 2023 (Urząd Miasta Łodzi, 2018b) have been set aside for the programme's implementation. In comparison, the annual total budgetary expenditure of the Lodz municipality in 2019 is about 4 billion PLN (ca. 1.1 billion EUR).

More recently, the authority has completed NCŁ, and the revitalisation programme has the potential to serve a promotional role: to change perceptions of Lodz, not only in the eyes of local residents, but also, more widely, in Poland and abroad. In other words, the process of urban change can promote Lodz as a whole, and not only the outcomes of the change. The municipality announced a bid to organise Specialised EXPO 2022 under the theme 'City Re:Invented'. The bid placed the expo site in the city centre (mostly NCŁ). Focusing on the notion of urban regeneration, the authority presented the city as being deeply involved in rethinking urban futures and as a leader of multi-dimensional urban revitalisation programmes. Furthermore, the aim of hosting the exposition was to boost the transformation of Lodz even more, to raise the profile of the city for worldwide audiences and to develop tourism. The bid

\footnotetext{
${ }^{1}$ After a period of literally no national urban policy in Poland one can observe a shift in 2015, when a government document concerning urban policy was adopted ('National Urban Policy 2023'; 'Krajowa Polityka Miejska 2023'). It expressed the need to counteract urban sprawl, giving priority to brownfield redevelopment, and implementing systemic revitalisation programmes (considering economic, technical, social and environmental issues), as well as adapting Polish cities for their ageing societies. Moreover, the policy stressed the important role of participative governance, the need for stronger cooperation between self-governments the within metropolitan areas and a need for the more rational and sustainable use of resources (land, water, energy) (Rada Ministrów RP, 2015). One of the consequences of this approach was the financial support of central government for problematic cities in Poland, which took the form of allocating and streaming EU funds for revitalisation programmes and provisioning legal frameworks.
} 
eventually came second, as in November 2017 the Bureau of International Expositions awarded the organisation of the Specialised EXPO 2022 to Buenos Aires.

The municipality remained determined to organise an event of worldwide appeal. Following the decision of the International Association of Horticultural Producers (IAHP) in March 2018, the mayor announced that Lodz would be hosting the Horticultural Expo in 2024 around the theme of 'Nature of the City'. In contrast to the Specialised EXPO 2022 bid, the Horticultural Expo 2024 application was rushed and was not widely discussed with local residents (or indeed local horticultural producers). The organisational and financial details following the win were not openly discussed or publicised, resulting in low public support for the event as well as initiatives to block it (Bujalski, 2019).

\section{Discussion and Conclusions}

Contemporary Lodz displays characteristics that, in many respects, typify post-socialist and post-industrial cities in transition. Despite a relatively strong basis for growth - in terms of population size and the presence of HEIs - Lodz suffered deep economic turmoil as a result of the decline of the textile and clothing industries. Consequent population loss and deprivation triggered by high unemployment negatively affected Lodz's competitiveness. Moreover, spatial proximity to the thriving Warsaw induced backwash effects (e.g. brain drain). Lodz's economic decline, therefore, appears more severe than in similar-sized post-industrial cities of the West described comprehensively by Power et al. (2010) and Carter (2016).

The economy of Lodz has evolved organically, with limited support of the national government. The dynamic growth of SMEs initially helped to overcome the post-transformation economic downfall. Although it is often forgotten in the public discourse, the textile and clothing industries remain an important component of the local and regional economy, albeit weakened and structurally different. Nowadays, these industries develop towards the 'smart specialisation' of the Lodz region (Urząd Marszałkowski Województwa Lódzkiego, 2014), investing in hi-tech materials and catering for specialist uses (e.g. medical and military).

Since the mid-2000s, Lodz has begun to attract transnational corporations. Initially, the majority of foreign investments focused on establishing new production sites with low-skilled job opportunities. The logistics sector created a high number of employment opportunities, as it flourished in the metropolitan area in response to the strategic position of the city within the newly constructed motorway network. Today, the Lodz metropolitan area is ranked $5^{\text {th }}$ among modern warehouse markets in Poland, with a supply of 1,370,000 $\mathrm{m}^{2}$ (Colliers International, 2017). Furthermore, Lodz was recently named 'the best performing market' outside Western Europe among Europe's most desirable logistics locations (Prologis, 2017).

Once an industrial metropolis without a single HEI, Lodz became the fifth largest university community in Poland in terms of the size of the full-time student population (Zasina, 2017). The remarkable, steady growth of the higher education industry has supplied Lodz's economy with a pool of graduates (Sokołowicz, 2018). Their availability changed Lodz's restructuring trajectory, as the city has attracted many white-collar jobs in recent years. This, in turn, has resulted in a boom in the commercial space market, fuelled by the demand of foreign and local BPO/ITO companies. According to Colliers International (2017), Lodz was the sixth largest 
regional office market in Poland in 2016, offering 360,000 $\mathrm{m}^{2}$ of modern office space, with the lowest vacancy rate $(6.2 \%$ in 2016$)$.

The past 25 years have also brought an evolutionary rise in awareness of the city's heritage potential. Adapting industrial sites to new uses brings impressive outcomes; however, the process takes time. Red-brick factories today are regenerated to house shopping centres, highclass offices, hotels, apartments, museums, leisure facilities, and HEIs. Currently, Lodz is entering a new stage of redevelopment, as publicly funded projects are underway to help revitalise the most deprived areas of the centre and to create NCŁ, a new, mixed-use residential and business district.

[Figure 11. near here]

[Figure 12. near here]

The unemployment rate in Lodz has decreased in recent years (Fig. 12), in line with nationwide trends. However, the social costs of the transformation are still palpable, and the depopulation continues. Between the collapse of communism in 1989 and 2015, Lodz's population shrank by $19.5 \%(166,405)$. Although depopulation commonly affects Polish cities of all sizes (Zasina, 2016), in Lodz, the process started earlier and has been more pronounced than in comparable cities (Szukalski, 2015). In light of the long-term demographic forecast, Lodz's population is expected to continue decreasing, falling below 500,000 in 2050 (Główny Urząd Statystyczny, 2014) (Fig. 11).

Lodz is, therefore, going to be confronted with new challenges. Current efforts to revitalise the centre, strengthen local identity, and position the city in the national and European hierarchy, will be followed by a set of objectives targeted at mitigating the effects of population loss. This new policy agenda requires a conscious, forward shift in strategy, to sustainably manage the anticipated processes. Better and tailored public services enhancing the quality of life, programmes concerning the retention of graduates, and balancing the use of resources and networks to shrinking demand, are of crucial importance to investigate and implement in the coming years.

In conclusion, in this paper, we characterised the evolving and changing nature of the ongoing post-industrial and post-socialist restructuring of Lodz, and interpreted its by distinct stages. We perceive the first stage — until the mid-2000s — as mostly 'organic', 'spontaneous' and of a 'bottom-up' character: the entrepreneurial explosion, the growth of HEIs and their investments, the initiatives of local social leaders and some of the first brownfield redevelopments carried out by private (mostly foreign) companies all happened with limited involvement of the local authority. However, in the early 2010s, this began to change, as some initiatives conceptualised by local activists were adopted by the public authorities into the policies of Lodz's development. Together with the wider availability of EU and national funds, the implementation of these proposals effectively shaped the emerging cityscape. This, in our opinion, marks the beginning of the second stage of the regeneration. Today, the restructuring of Lodz bears similarities to other European examples, which focused on large projects and events. To us, the second stage of the restructuring of Lodz appears to be partly a result of the first stage; however, the importance of organic initiatives has diminished. This raises important 
questions about the consequences of the current model of Lodz's restructuring and the prospects for the city. The coming decades will show us how resilient the evolving model of urban restructuring of Lodz is, and to what extent it will be able to maintain the dynamics of changes.

\section{References}

1. Badziak, K. (2009). Zarys dziejów Łodzi do 1918 roku. In S. Liszewski (Ed.), Łódź. Monografia miasta (pp. 27-61). Łódź: Łódzkie Towarzystwo Naukowe.

2. Borkowska, S., \& Bohdziewicz P. (Eds.). (1994). Rynek pracy w makroregionie łódzkim. Łódź: Wydawnictwo Uniwersytetu Łódzkiego.

3. Boryczka, E. M. (2013). Town Centre Management. Koncepcja zarządzania centrum miasta na przykładzie miast europejskich. Zeszyty Naukowe Politechniki Częstochowskiej "Zarządzanie”, 12, pp. 119-130.

4. Buchner-Jeziorska, A., \& Kulpińska, J. (1996). Rola uniwersytetu w aglomeracji przemysłowej. Przykład Łodzi. Nauka i Szkolnictwo Wyższe, 8(2), pp. 61-67.

5. Bujalski S. (2019). Zielone expo. Czy Łódź straci największa impreze w swej historii? Rzad krytykuje, miasto uspokaja. "Gazeta Wyborcza", June 26th, 2019. Online access: http://lodz.wyborcza.p1/lodz/7,35136,24934247,zielone-expo-czy-lodz-stracinajwieksza-impreze-w-swej-historii.html

6. Carter, D. K. (Ed.). (2016). Remaking Post-Industrial Cities: Lessons from North America and Europe. New York City, NY: Routledge.

7. Colliers International. (2017). Łódź Real Estate Market 2017. Łódź: Urząd Miasta Łodzi.

8. Dzieciuchowicz, J. (2009a). Ludność Łodzi do 1918 roku. In S. Liszewski (Ed.), Łódź. Monografia miasta (pp. 113-124). Łódź: Łódzkie Towarzystwo Naukowe.

9. Dzieciuchowicz, J. (2009b). Ludność Łodzi od 1918 roku do lat 90. XX wieku. In S. Liszewski (Ed.), Łódź. Monografia miasta (pp. 265-296). Łódź: Łódzkie Towarzystwo Naukowe.

10. Dzieciuchowicz, J. (2009c). Przemiany ludnościowe Łodzi na przełomie XX i XXI wieku. Prognoza demograficzna Łodzi. In S. Liszewski (Ed.), Łódź. Monografia miasta (pp. 381-399). Łódź: Łódzkie Towarzystwo Naukowe.

11. Fleming, M. (2012). Legitimating Urban "Revitalisation" Strategies in Post-socialist Łódź. East European Politics \& Societies, 26(2), pp. 254-273. http://doi.org/10.1177/0888325411415400.

12. Gałuszka, J. (2017). Examining patterns of policy change in a post-socialist city: the evolution of inner-city regeneration approaches in Łódź, Poland, after 1989. Town Planning Review, 88(6), pp. 639-664. http://doi.org/10.3828/tpr.2017.39.

13. Główny Urząd Statystyczny. (2014). Łódź population projection 2015-2050. Warszawa: Główny Urząd Statystyczny.

14. Główny Urząd Statystyczny (2017). Bank Danych Lokalnych. Online access on October 10th, 2017. https://bdl.stat.gov.pl/ BDL/start. 
15. Hanzl, M. (2011). Redeveloping the City Structure - the case of Lodz "New City Center" (pp. 1-10). Presented at the REAL CORP. Change for Stability. Lifecycles of Cities and Regions, Essen.

16. Jakóbczyk-Gryszkiewicz, J., Marcińczak, S., \& Wolaniuk, A. (2014). Gentrification processes in the city. In T. Marszał (Ed.), Society and space in contemporary Poland in Łódź University Geographical Research (pp. 83-111). Łódź: Wydawnictwo Uniwersytetu Łódzkiego.

17. Jewtuchowicz, A. (2013). Terytorium i współczesne dylematy jego rozwoju. Łódź: Wydawnictwo Uniwersytetu Łódzkiego.

18. Jewtuchowicz, A., \& Suliborski, A. (2009a). Kształtowanie się funkcji gospodarczych Łodzi do 1918 roku. In S. Liszewski (Ed.), Łódź. Monografia miasta (pp. 125-149). Łódź: Łódzkie Towarzystwo Naukowe.

19. Jewtuchowicz, A., \& Suliborski, A. (2009b). Struktura gospodarcza Łodzi w latach 1918-1989. In S. Liszewski (Ed.), Łódź. Monografia miasta (pp. 297-322). Łódź: Łódzkie Towarzystwo Naukowe.

20. Jewtuchowicz, A., \& Suliborski, A. (2009c). Gospodarka Łodzi na przełomie XX i XXI wieku. In S. Liszewski (Ed.), Łódź. Monografia miasta (pp. 400-409). Łódź: Łódzkie Towarzystwo Naukowe.

21. Kowalski, K., Matera, R., Sokołowicz, M.E. (2018). Cotton Matters. A Recognition and Comparison of the Cottonopolises in Central-Eastern Europe during the Industrial Revolution. Fibres and Textiles in Eastern Europe, 132, pp. 16-23, http://doi.org/ 10.5604/01.3001.0012.5162.

22. Kwiek, M. (2015). Prywatyzacja i deprywatyzacja: od ekspansji do implozji szkolnictwa wyższego w Polsce. Praktyka Teoretyczna, 3, pp. 120-145.

23. Liszewski, S. (Ed.). (2009). Łódź. Monografia miasta. Łódź: Łódzkie Towarzystwo Naukowe.

24. Marczyńska-Witczak, E., \& Starzyńska, W. (2002). Procesy dezindustrializacji w aglomeracji łódzkiej w latach dziewięćdziesiątych. Acta Universitatis Lodziensis Folia Geographica Socio-Oeconomica 4, pp. 25-32.

25. Markowski, T., \& Turała, P. (2007). Charakterystyka Zintegrowanego Programu Rewitalizacji Obszarów Centralnych Łodzi - PROREVITA. In T. Markowski \& D. Stawasz (Eds.), Rewitalizacja a rozwój funkcji metropolitalnych miasta Łodzi (pp. 6784). Łódź: Wydawnictwo Uniwersytetu Łódzkiego.

26. Nowakowska, A., \& Walczak, B. (2016). Dziedzictwo przemysłowe jako kapitał terytorialny. Przykład Łodzi. Gospodarka w Praktyce i Teorii, 45(4), pp. 1-12. http://doi.org/10.18778/1429-3730.45.04.

27. Power, A., Plöger, J., \& Winkler, A. (2010). Phoenix Cities. The fall and rise of great industrial cities. Bristol: The Policy Press.

28. Rada Ministrów RP (2015). Krajowa Polityka Miejska, Resolution No. 198 of The Council of Ministers of the Republic of Poland on October 20th, 2015.

29. Riley, R. (1997). Central Area Activities in a Post-communist City: Łódź, Poland. Urban Studies, 34(4), 453-470.

30. Rzeńca, A., \& Sokołowicz, M. E. (2017). Events and Places: What Strategies for Cities and Regions Marketing? Remarks on Event Sector Development in the Post-Industrial 
City of Łódź (Poland). In. A. Dias, B. Salmelin, D. Pereira \& M. S. Dias (Eds.), Modeling Innovation Sustainability and Technologies. Economic and Policy Perspectives (pp. 191-204). Cham: Springer. http://doi.org/10.1007/978-3-319-671017_15.

31. Sokołowicz, M.E. (2013). Is the community of Łódź informed about living in creative city? City of Łódź' branding strategy and its perception. Studia Ekonomiczne. Zeszyty Naukowe Uniwersytetu Ekonomicznego w Katowicach, 149, pp. 256-267.

32. Sokołowicz, M. E. (2018). Student cities or cities of graduates? The case of Lodz and its students declared preferences. Population, Space and Place, 70(2), e2177-16. http://doi.org/10.1002/psp.2177

33. Sokołowicz, M. E., \& Zasina, J. (2016). Sektor kultury jako czynnik transformacji miasta przemysłowego w kierunku miasta kreatywnego i inteligentnego? Przykład Łodzi. Acta Universitatis Lodziensis Folia Oeconomica, 324(4), pp. 5-19. http://doi.org/10.18778/0208-6018.324.01.

34. Stefański, K. (2001). Jak zbudowano przemysłową Łódź. Architektura i urbanistyka miasta w latach 1821-1914. Łódź: Regionalny Ośrodek Studiów i Ochrony Środowiska Kulturowego w Łodzi.

35. Szukalski P. (2015). Sytuacja demograficzna Łodzi na tle innych wielkich polskich miast. In Szukalski P. (Ed.), Procesy demograficzne w województwie łódzkim w XXI wieku (pp. 145-170). Łódź: Wydawnictwo Uniwersytetu Łódzkiego.

36. Wolaniuk, A. (2010). Uniwersytety i ich rola w organizacji przestrzeni. Łódź: Wydawnictwo Uniwersytetu Łódzkiego.

37. Young, C., \& Kaczmarek, S. (2008). The Socialist Past and Postsocialist Urban Identity in Central and Eastern Europe. European Urban and Regional Studies, 15(1), 53-70.

38. Zasina, J. (2016). The Emergence of Households and Urbanization Patterns in Poland. Datutop, 34, pp. 83-102.

39. Zasina, J. (2017). W kierunku studentyfikacji? Zakwaterowanie studenckie w polskich miastach akademickich. Gospodarka w Praktyce $i$ Teorii, 47, pp. 69-84.

40. Zysiak, A. (2016). Punkty za pochodzenie. Powojenna modernizacja i uniwersytet w robotniczym mieście. Kraków: Nomos.

41. Zysiak, A., Śmiechowski, K., Piskała, K., Marzec, W., Kaźmierska, K., Burski, J. (2018). From Cotton and Smoke. Łódź - Industrial City and Discourses of Asynchronous Modernity 1897-1994. Łódź: Wydawnictwo Uniwersytetu Łódzkiego.

42. Urząd Marszałkowski Województwa Łódzkiego. (2014). Regionalny Program Operacyjny Województwa Łódzkiego na lata 2014-2020. Łódź: Urząd Marszałkowski Województwa Łódzkiego.

43. Urząd Miasta Łodzi. (2009), Łódź Brand Management Strategy for the Years 20102016. Łódź: Urząd Miasta Łodzi.

44. Urząd Miasta Łodzi (2018a). Łódź 2026+ Revitalization Program. Communal Revitalization Program, Resolution No. LXXIII/1980/18 of the City Council of Łódź on July 5th, 2018.

45. Urząd Miasta Łodzi (2018b). Resolution No. III/67/18 of the City Council of Łódź on December 27th, 2018. 
46. Urząd Statystyczny w Łodzi (2017). Socio-economic situation in Łódź. Łódź: Urząd Statystyczny w Łodzi.

47. Walker, A. R. (1993). Lodz: The Problems Associated with Restructuring the Urban Economy of Poland's Textile Metropolis in the 1990s. Urban Studies, 30(6), pp. 10651080. 


\section{Figures}

Figure 1.

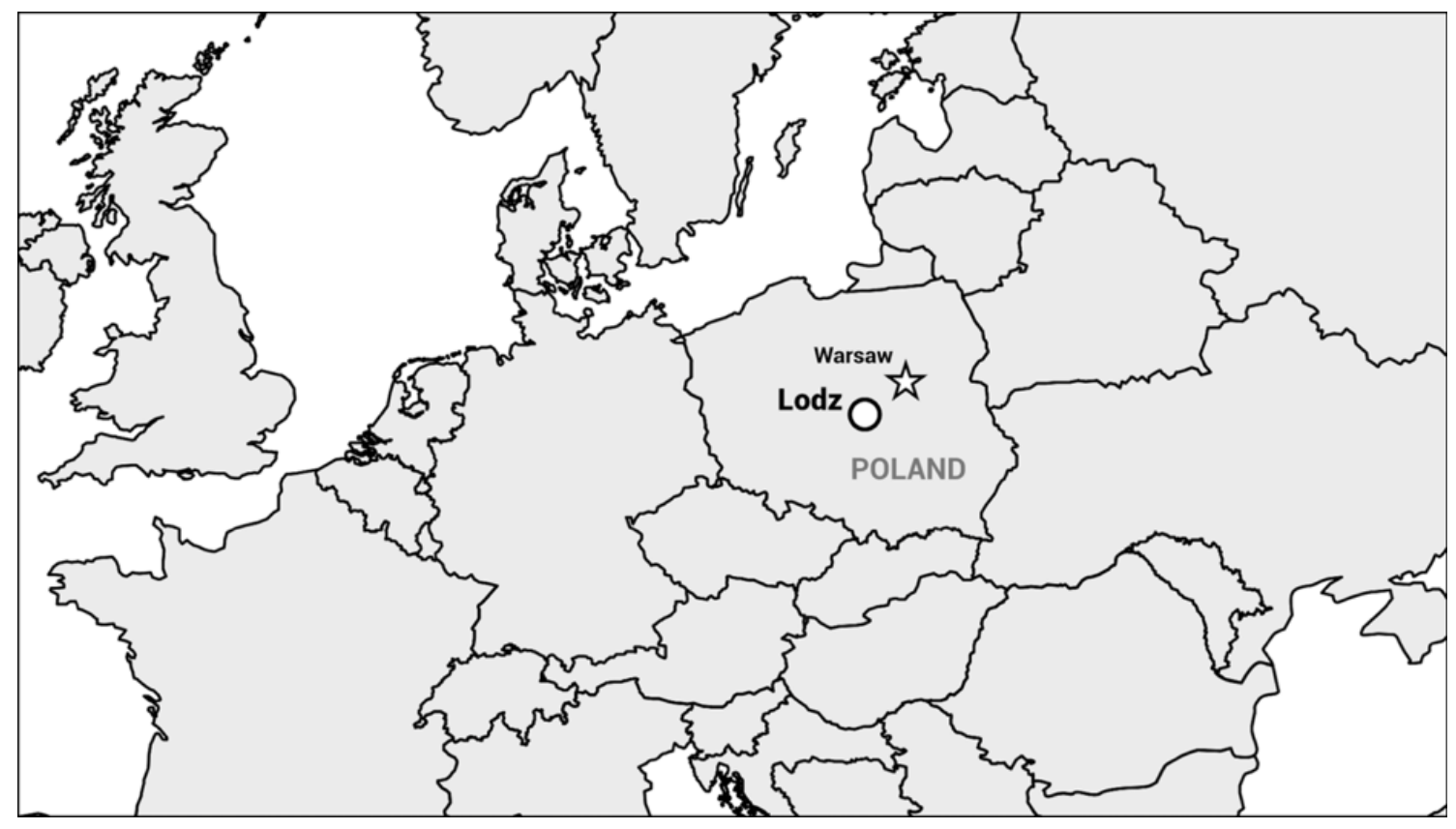

Figure 2.

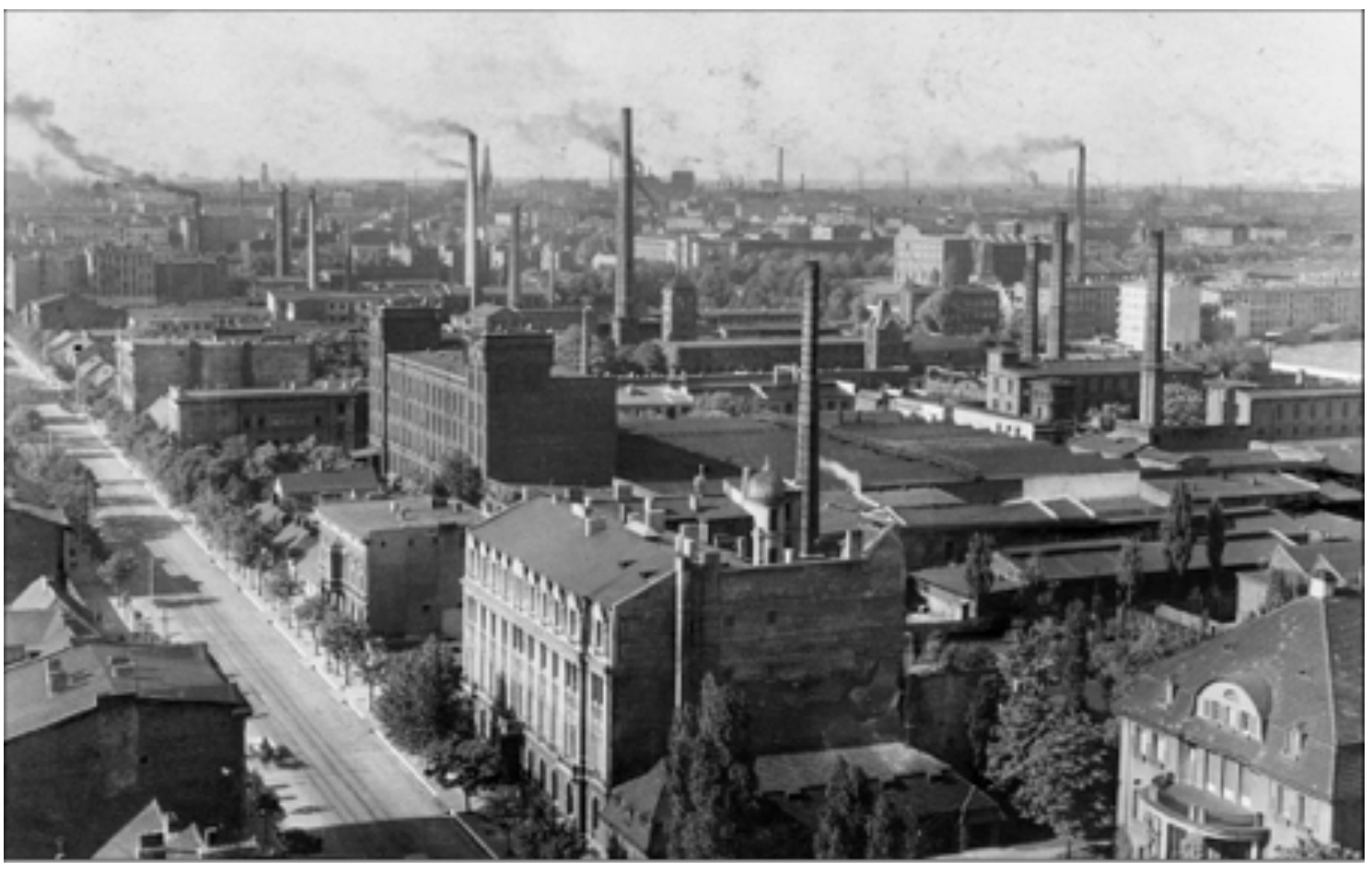


Figure 3.

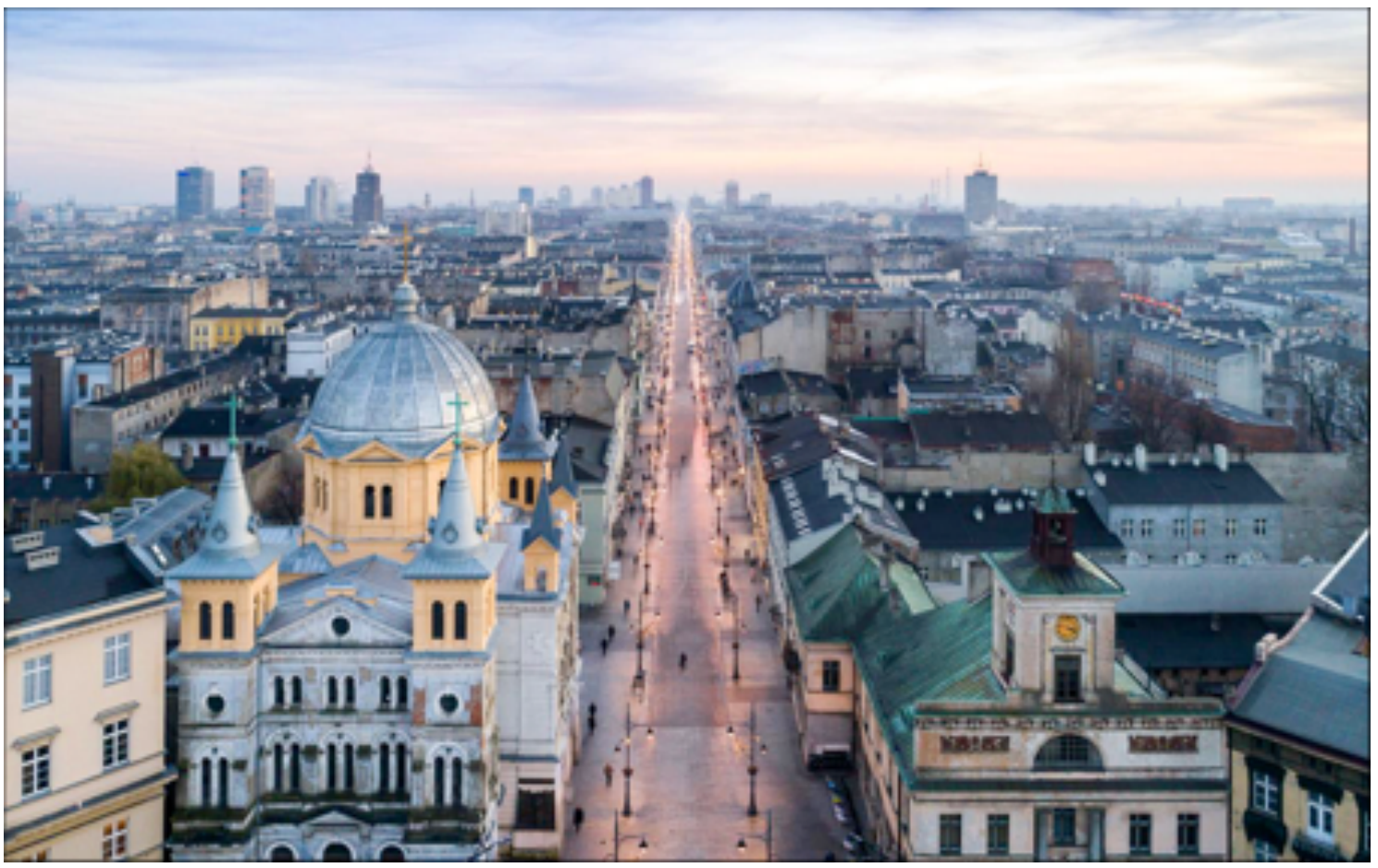


Figure 4.

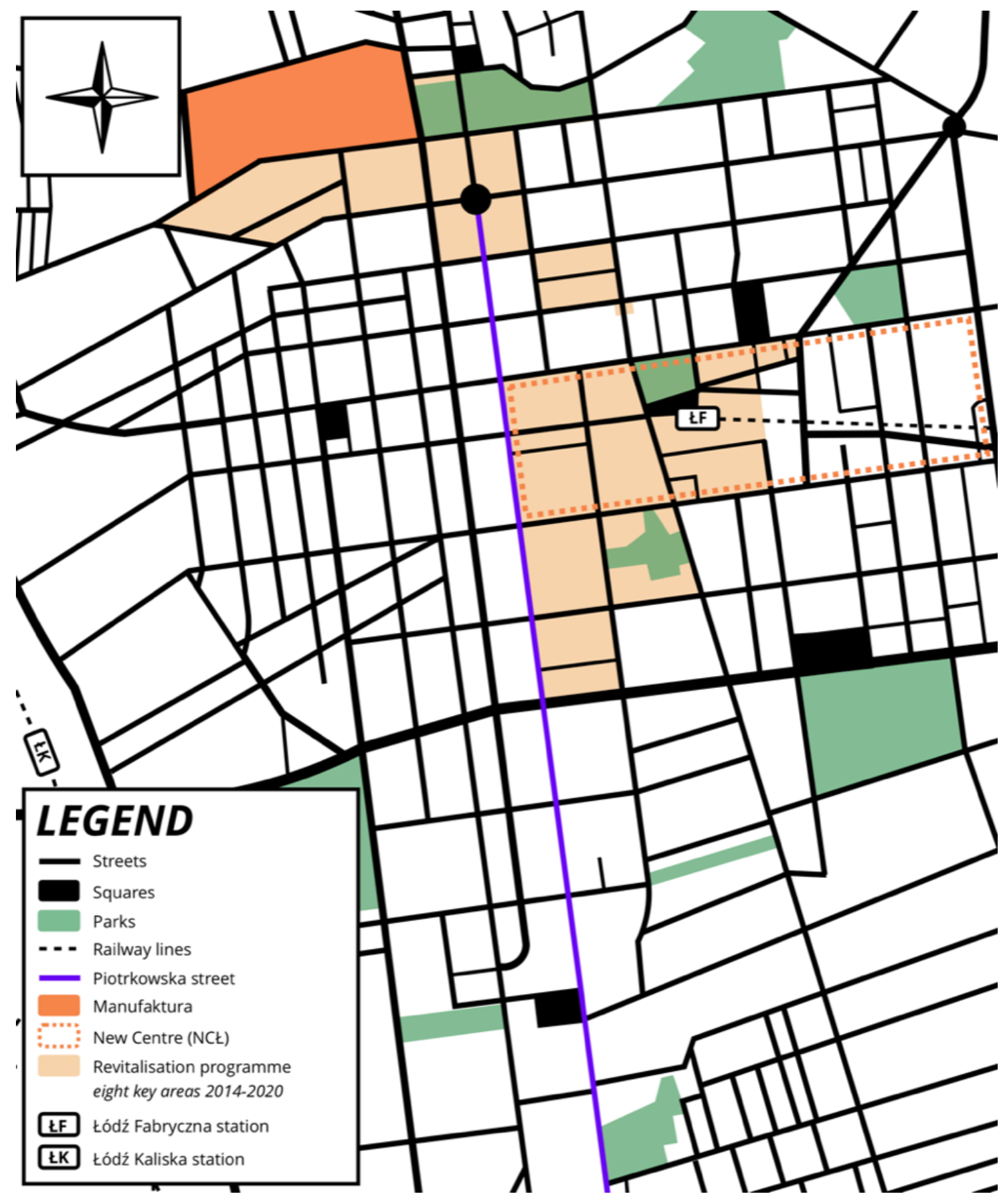


Figure 5.

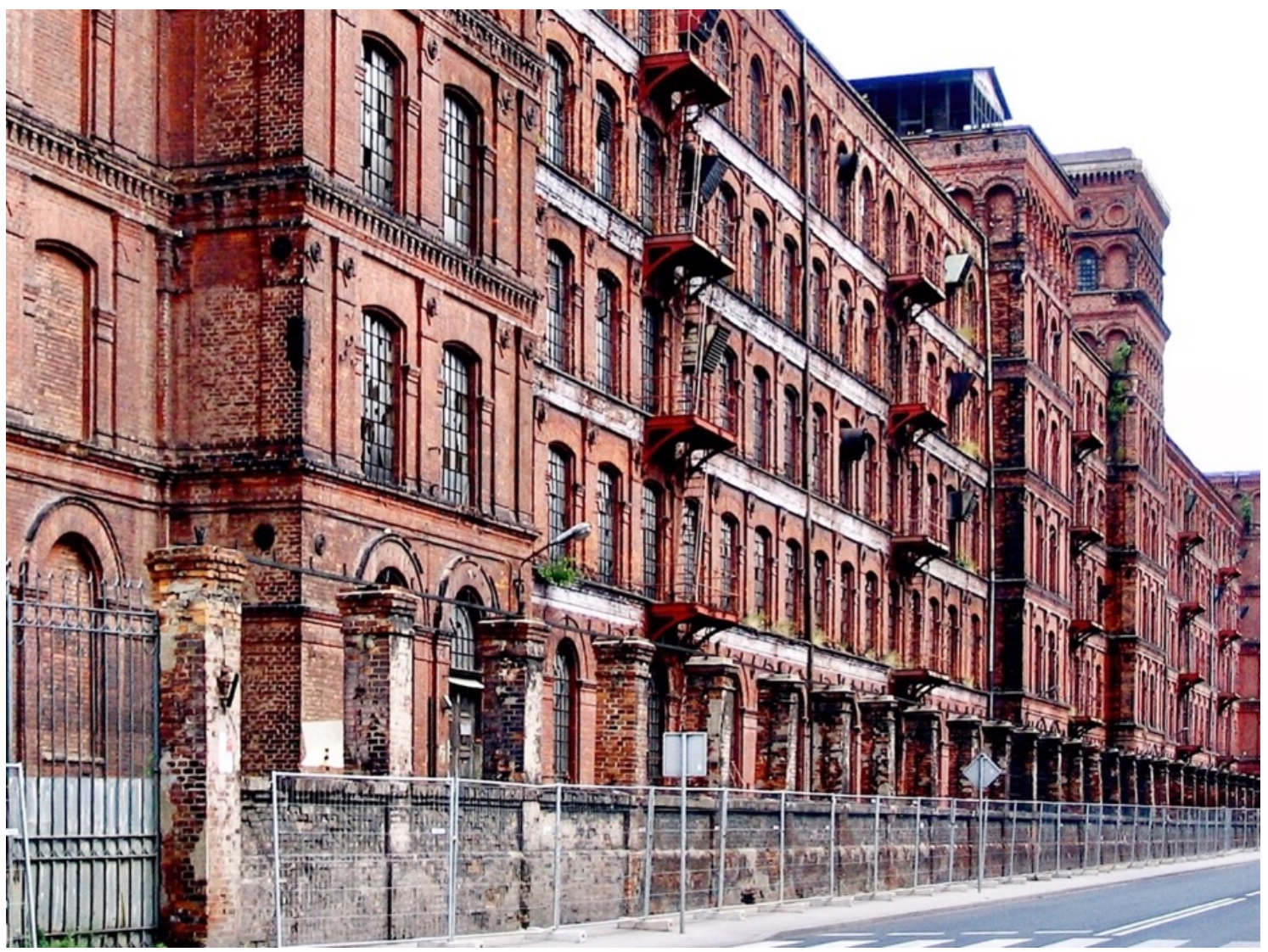

Figure 6.

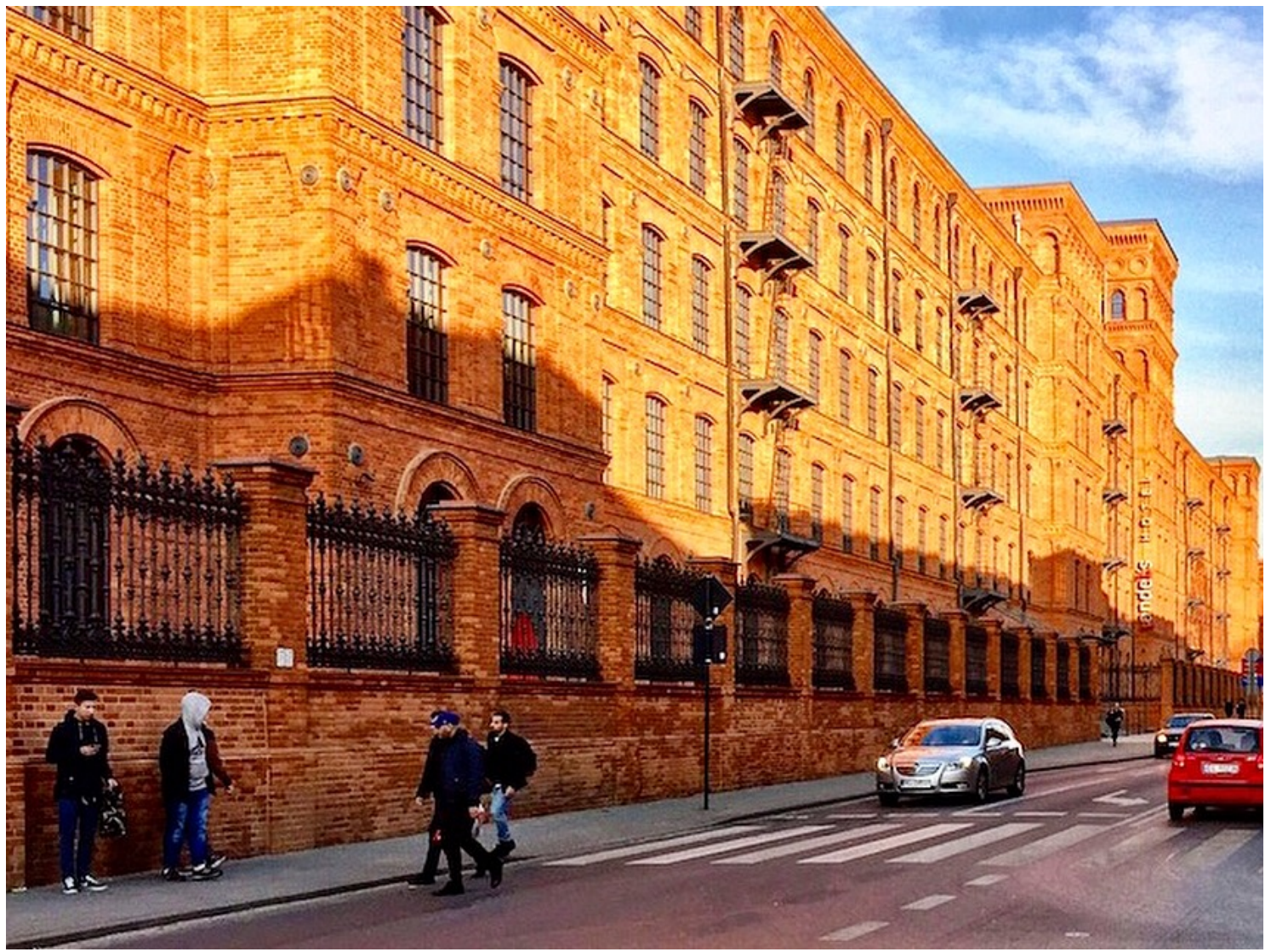


Figure 7.

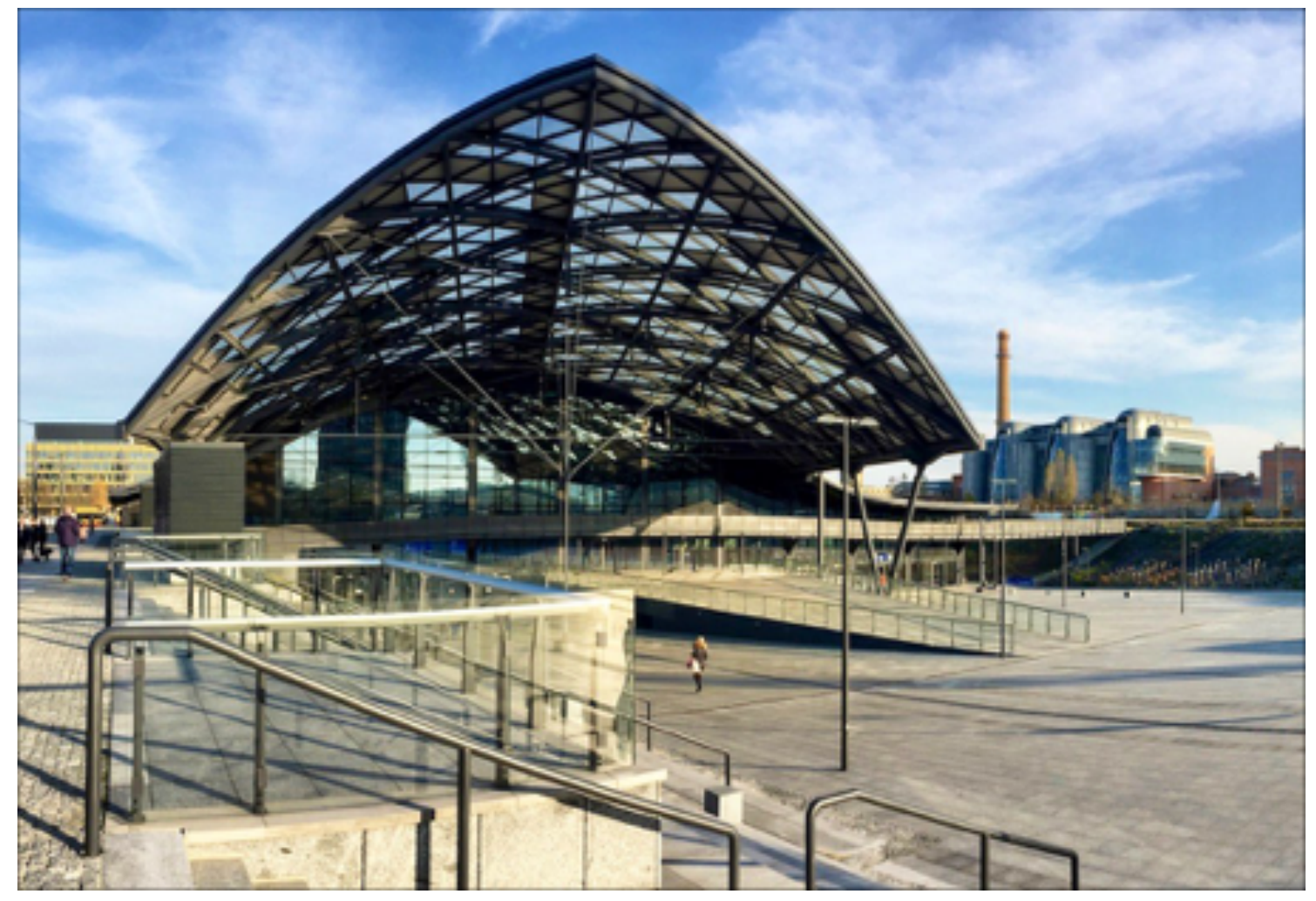

Figure 8.

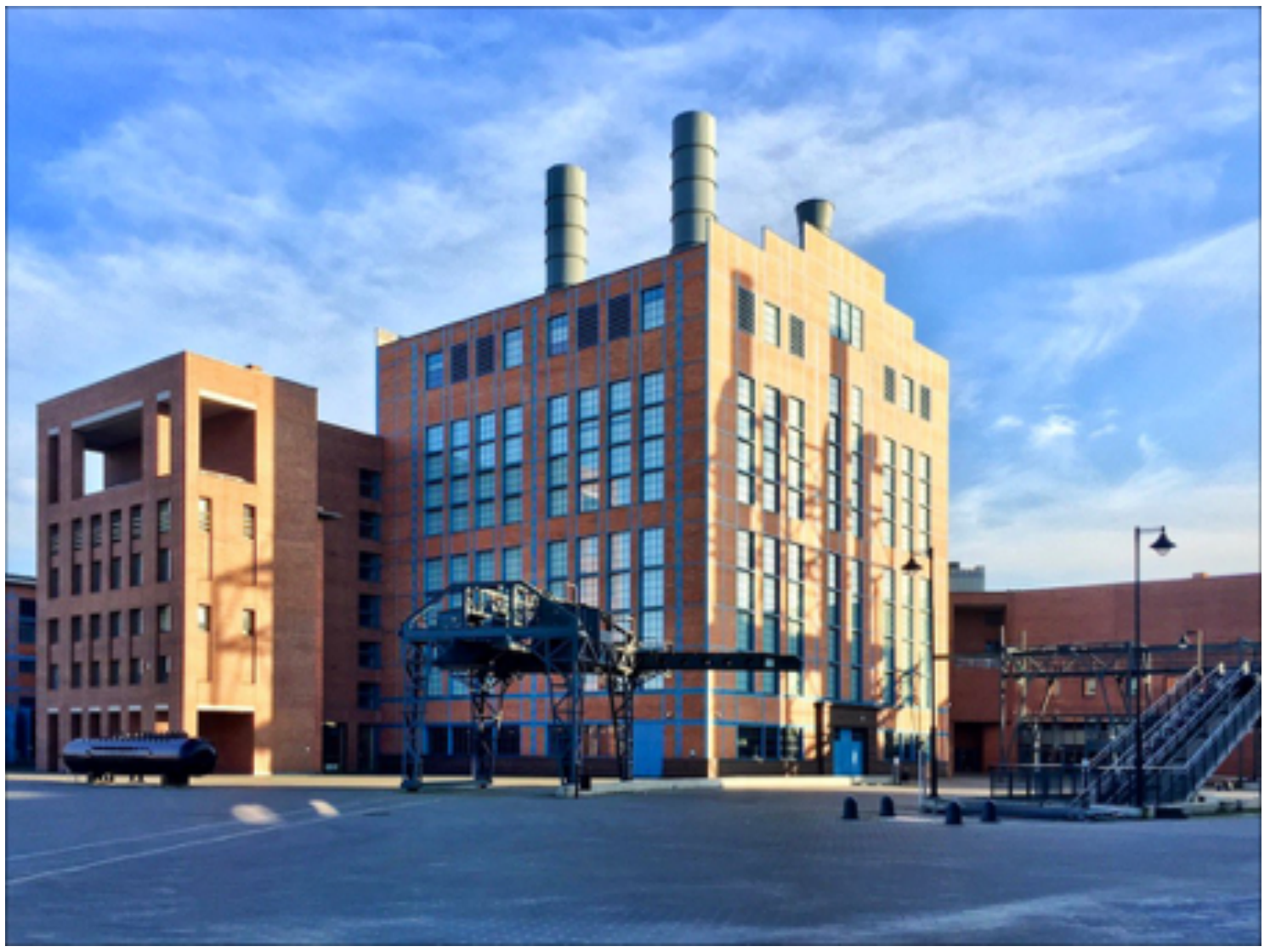


Figure 9.

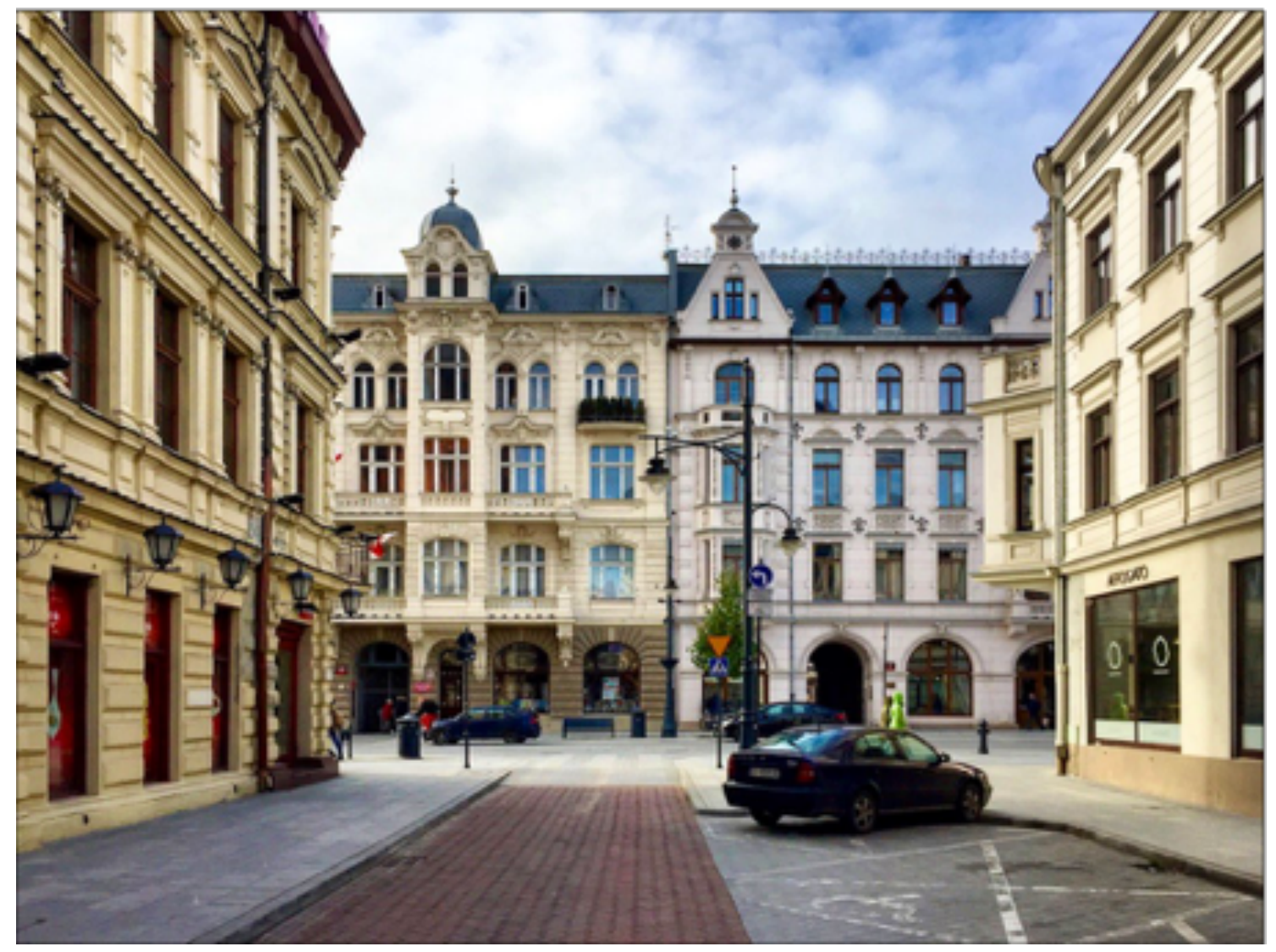

Figure 10.

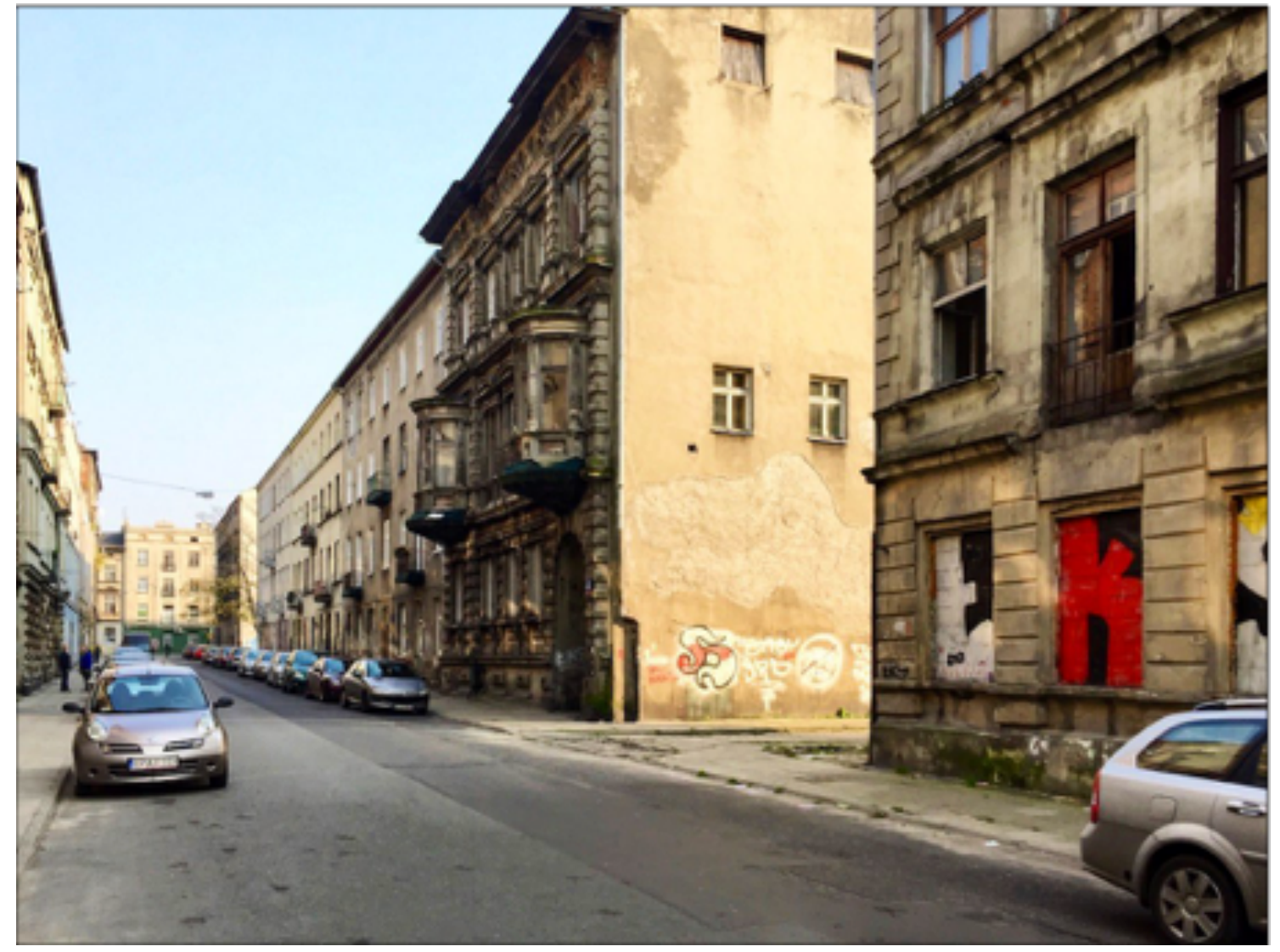


Figure 11.

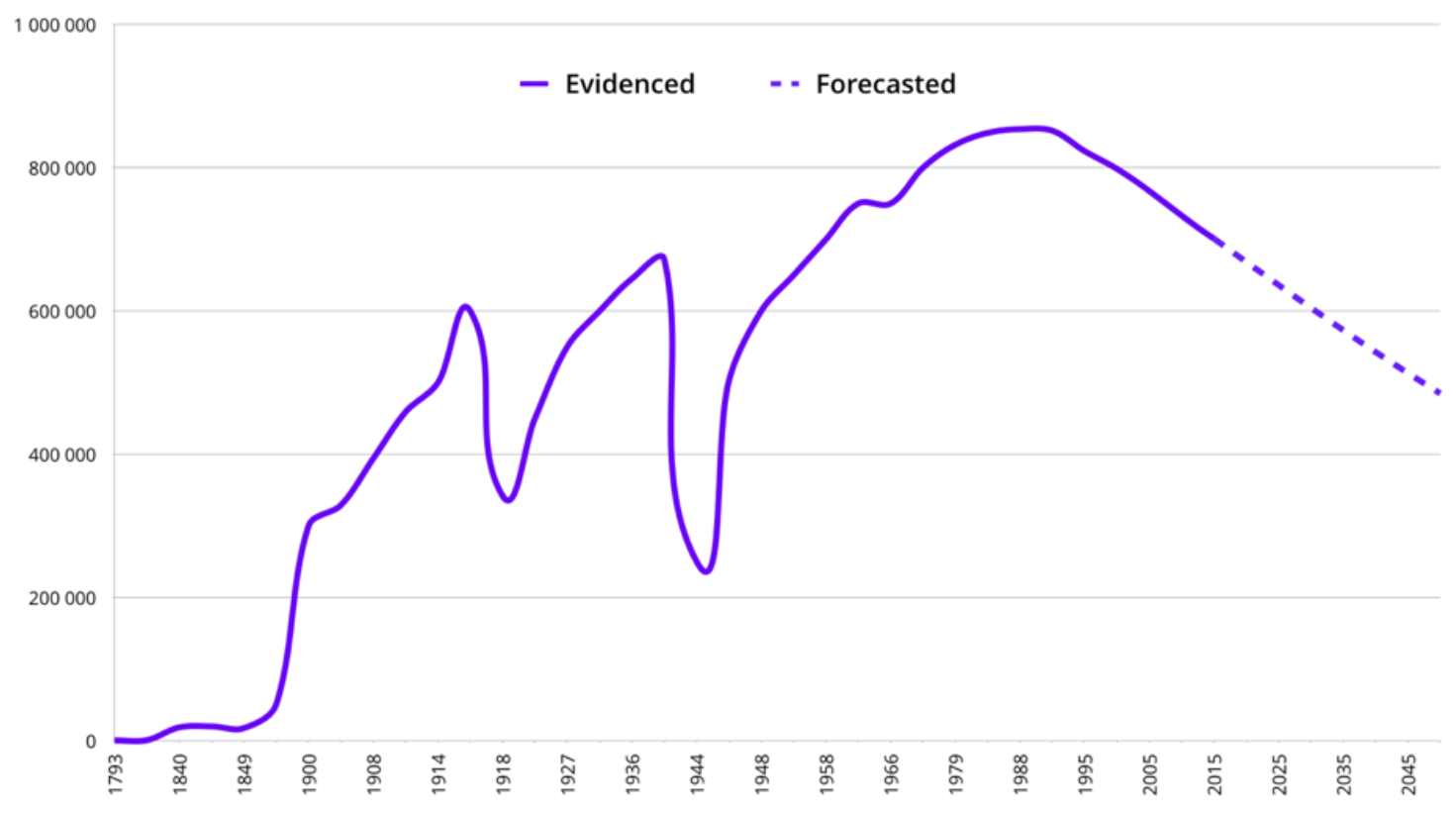

Figure 12.

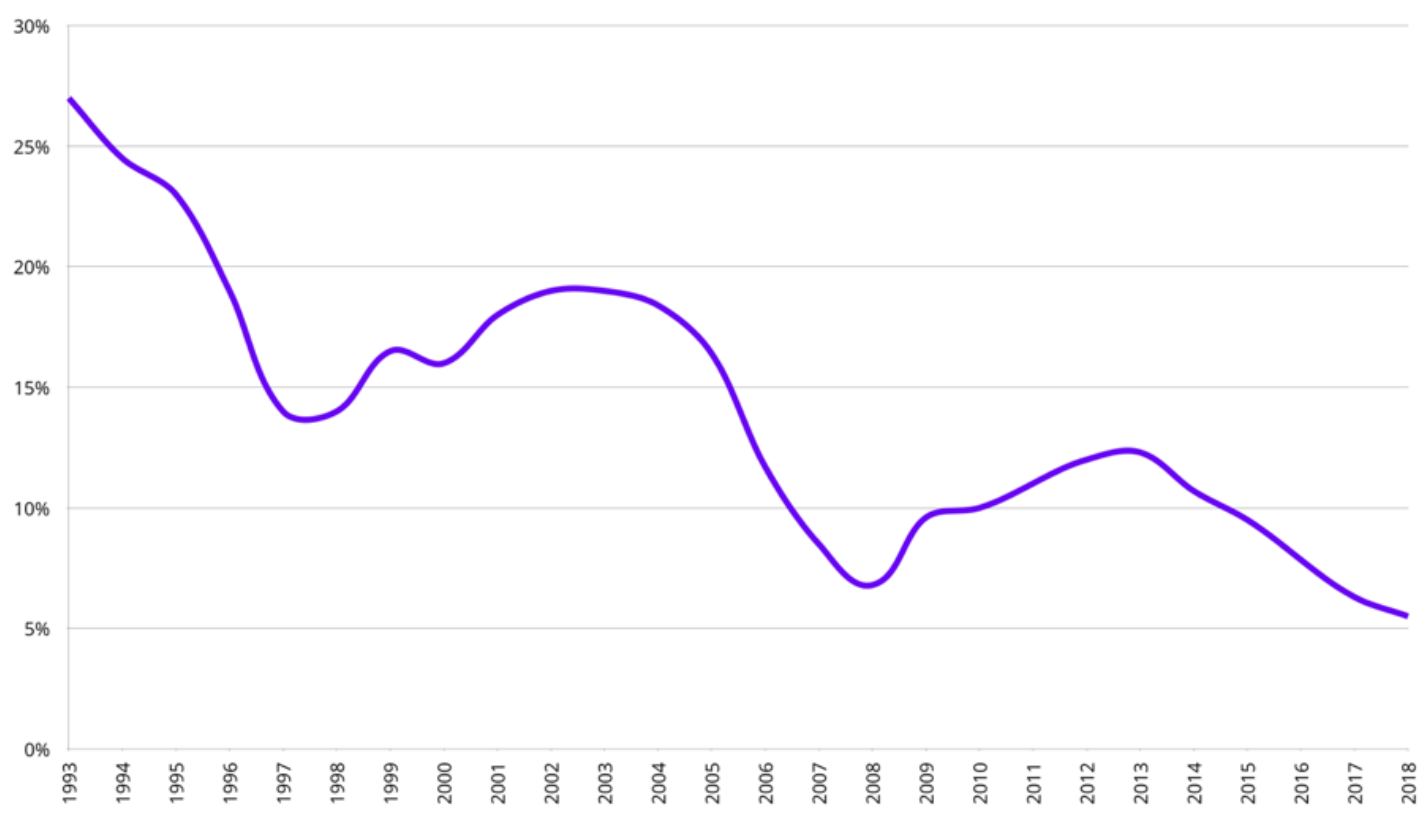




\section{Figures captions}

- Figure 1. The location of Lodz. Source: Own contribution.

- Figure 2. The cityscape of Lodz in the interwar period. Source: Narodowe Archiwum Cyfrowe.

- Figure 3. Piotrkowska Street in Lodz. Author: Rafał Tomczyk. Source: www.4wymiar.com, 2017.

- Figure 4. Lodz's centre and its spatial development. Source: Own contribution.

- Figures 5. A former industrial site before transformation into the 'Manufaktura' commercial centre. Author: Jakub Zasina, 2005.

- Figures 6. A former industrial site after transformation into the 'Manufaktura' commercial centre. Author: Jakub Zasina, 2017.

- Figures 7. The key public investment in the NCE area Łódź Fabryczna railway station. Author: Jakub Zasina, 2017.

- Figures 8. The key public investment in the NCŁ area - EC1 Museum. Author: Jakub Zasina, 2017.

- Figures $9 \& 10$. Contrasts between the Lodz's inner-city neighbourhoods. Author: Jakub Zasina, 2017.

- Figure 11. The population of Lodz. Source: Own research based on Liszewski, 2009; Główny Urząd Statystyczny, 2014, 2017.

- Figure 12. The unemployment rate in Lodz. Source: Own research based on Dzieciuchowicz, 2009c; Główny Urząd Statystyczny, 2017. 


\section{Funding}

Jakub Zasina's portion of this work was supported by the National Science Centre in Poland (grant agreement no. 2016/23/N/HS4/03390). 